\title{
PREDICTORS OF PERSISTENT POST TRANSPLANT HYPERPARATHYROIDISM (HPTX)
}

\author{
Fatores Preditores de Hiperparatireoidismo Persistente pós-Transplante Renal
}

\author{
Luiz Roberto Sousa Ulisses', Leonardo Figueiredo Camargo 1 , Marcos Vinícius de Sousa ${ }^{1}$, Carla Feitosa do Vale1, \\ Gabriel Giollo Rivelli', Marilda Mazzali'.
}

\begin{abstract}
Post transplant persistent Hyperparathyroidism (HPTx) increases the risk for transplant complications. Purpose: to identify risk factors for HPTx in the first post transplant year. Methods: Retrospective analysis of medical records from renal transplant recipients from July/2008 to December/2010. Inclusion criteria: serum PTH $\geq 500 \mathrm{pg} / \mathrm{ml}$ at transplant and normal 1-year graft function (serum creatinine $\leq 2 \mathrm{mg} / \mathrm{dL}$ ). From a group of 224 renal transplants, 69 (30\%) fulfilled the inclusion criteria, and they were divided in 2 groups, according to the serum PTH after 1 year of transplant: control, 1 -year PTH<150 pg/ml $(n=32)$ and Persistent Hyperparathyroidism, HPTx, 1-year PTH $\geq 150 \mathrm{pg} / \mathrm{ml}(\mathrm{n}=37)$. Data analyzed: serum calcium $(\mathrm{Ca})$, phosphate $(\mathrm{Pi})$, alkaline phosphatase $(\mathrm{AP}), \mathrm{PTH}$ and glomerular filtration rate (GFR) at transplant, and 3, 6 and 12 months post transplant. Results: At transplant, the groups were comparable as to age, $\mathrm{Pi}$ and PTH. However, the length of the dialysis $(78 \pm 40$ vs. $50 \pm 34$ months, $\mathrm{p}<0.05)$ and $\mathrm{Ca}(8,9 \pm 0.9 \mathrm{vs} .8,5 \pm 0,6 \mathrm{mg} /$ $\mathrm{dL}, \mathrm{p}<0.05$ ) were higher in the HPTx group. After 3 months post transplant, HPTx group maintained higher PTH levels $(365.4 \pm 176.2$ vs. $166.9 \pm 92.2 \mathrm{pg} / \mathrm{mL}, p<0.05)$, and AP $(175 \pm 145$ vs. $109 \pm 52 \mathrm{UI}, \mathrm{p}<0.05)$, than controls, despite of the comparable $\mathrm{Ca}, \mathrm{Pi}$, and GFR. From the 6th post transplant month, the HPTx group persisted with hypercalcemia $(10.2 \pm 0.7$ vs. $9.9 \pm 0.5 \mathrm{mg} / \mathrm{dL}, p<0.05)$ and low phosphate $(2.6 \pm 0.5$ vs. $2.9 \pm 0.7, p<0.05)$ with higher AP and PTH levels than in controls $(p<0.05)$. At the end of the 1 post transplant year, HPTx group persisted with hypercalcemia, despite the recovery of the graft function while in the control group, the GFR recovery was associated with normalization of the bone mineral metabolism parameters. Conclusion: HPTx was associated with longer pre transplant dialysis therapy and higher $\mathrm{Ca}$ at transplant. Higher PTH and AP post transplant levels at the 3rd month were associated with persistent hyperparathyroidism, as well as persistent hypercalcemia and low phosphate, despite of the GFR recovery.
\end{abstract}

Keywords: Transplantation; Hyperparathyroidism; Hypercalcemia.

Institution

${ }^{1}$ Renal Transplant Unit, Division of Nephrology, Department of Medicine, School of Medical Sciences, State University of Campinas- UNICAMP- Campinas, São Paulo, Brazil

${ }^{1}$ Programa de Transplante Renal, Disciplina de Nefrologia- DCM/ FCM Unicamp- Campinas- São Paulo- Brasil

\section{Correspondence}

Marilda Mazzali, MD

Division of Nephrology, Department of Medicine School of Medical Sciences, State University of Campinas - DCM/FCM/UNICAMP -

Rua Tessália Vieira de Camargo, 126 - Cidade Universitária

Zeferino Vaz - 13083-970 - Campinas/SP - Brazil

Phone: 55-19-35218204 - fax: 55-19-3521-8208

E-mail: marildamazzali@gmail.com

Recebido em: 19/12/2014

Aceito em: 29/01/2015

\section{INTRODUCTION}

Chronic renal disease promotes major changes in the bone mineral metabolism. The reduction in the rate of glomerular filtration is associated with a lower synthesis of the active vitamin $D$ that reduces the intestinal calcium absorption, leading to hypocalcemia and stimulation of the parathyroid gland to synthetize PTH in order to restore calcium levels. PTH increases the bone reabsorption, increasing the serum calcium. However, persistent stimuli of the PTH synthesis results in nodular or diffuse parathyroid hyperplasia, leading to a down regulation of $\mathrm{Ca}$ and to vitamin $\mathrm{D}$ receptors, and hypercalcemia can be frequent. Concomitantly, it occurs an increase in the FGF-23 levels with increasing serum phosphate and calcium/phosphate product.1-3 
Luiz Roberto Sousa Ulisses, Leonardo Figueiredo Camargo, Marcos Vinícius de Sousa, Carla Feitosa do Vale, Gabriel Giollo Rivelli, Marilda Mazzali

Bone mineral disorders are frequent after renal transplantation. Clinical presentation includes higher calcium, phosphorus, PTH and FGF-23 levels in contrast to low vitamin $D$ and bone disease. The severity of hyperparathyroidism is related to the severity of morphological changes of the bone observed after renal transplantation. ${ }^{3,4}$

After renal transplant, the recovery of the graft function is associated with a rapid decline in PTH levels within 3 months, while the normalization of vitamin $D$ can take around 18 months. However, in 20 to $30 \%$ of patients, PTH levels remains high, despite of the recovery of the renal function. This condition, Persistent Hyperparathyroidism (HPTX) is characterized by hypercalcemia and low phosphate level. Hypercalcemia is a consequence of the increased intestinal calcium absorption and bone reabsorption mediated by $\mathrm{PTH}$. The production of active vitamin $D$ by normal graft also contributes to such mechanisms. ${ }^{1,4,5}$

Persistent hyperparathyroidism has a negative impact on graft function, with a higher incidence of delayed graft function and risk for kidney calcification and stones. Identifying risk factors for this disorder can improve the graft and patient survival. ${ }^{6}$

The aim of this study was to determine predictors to the development of persistent post transplant hyperparathyroidism (HPTx).

\section{PATIENTS and METHODS}

This retrospective study was approved by the local Ethics Committee. Transplant database and medical records of renal transplant recipients from July/2008 to December/2010, were recorded. The inclusion criteria considered: (a) patients with PTH $\geq 500 \mathrm{pg} / \mathrm{ml}$ at transplant; (b) serum creatinine $\leq 2.0 \mathrm{mg} / \mathrm{dL}$ at the end of 1 post transplant year; (c) age at transplant $>18$ years old. The exclusion criteria were: (a) pre transplant parathyroidectomy; (b) post transplant follow up $<6$ months; or (c) PTH levels unavailable to the analysis.

From a total of 224 renal transplant patients with PTH levels available at transplant, $69(30 \%)$ fulfilled the inclusion criteria. In order to analyze the risk for HPTx, patients were divided in 2 groups, according to the PTH levels 1 post transplant year: control-CTRL $(n=32)$, with $\mathrm{PTH}<150 \mathrm{pg} / \mathrm{ml}$, and persistent hyperparathyroidism group-HPTx ( $=33$ ), with PTH $\geq 150 \mathrm{pg} / \mathrm{ml}$.

Data collected from medical records included: serum calcium (Ca), phosphate (Pi), alkaline phosphatase (AP), PTH and estimated glomerular filtration rate, calculated by the MDRD formula. Data were collected at baseline (transplant time) and 3, 6 and 12 months after transplant. Statistical analysis was performed by the Statview Graphpad software, using the Student $t$ or chi-square tests. Significance was considered if $p<0.05$.

\section{RESULTS}

At baseline (transplant), the groups were comparable as to the age ( $46 \pm 9$ vs. $47.5 \pm 12$ years old, CTRL vs. HPTx, $\mathrm{p}=\mathrm{ns})$, serum phosphate $(5.3 \pm 1.8$ vs. $6.0 \pm 1.8 \mathrm{mg} / \mathrm{dL}$, CTRL vs. HPTx, $p=n s)$ and PTH levels $(929 \pm 644$ vs. $1137.6 \pm 578.3 \mathrm{pg} / \mathrm{ml}$, CTRL vs. HPTx, $\mathrm{p}=\mathrm{ns}$ ). However, the HPTx group had longer dialysis treatment time (78 \pm 40.3 vs. $49.9 \pm 34.5$ months, HPTX vs. CTRL, $p<0.05$ ) and higher calcium levels $(8.9 \pm 0.9$ vs. $8.5 \pm 0.6 \mathrm{mg} /$ $\mathrm{dL}$, HPTX vs. CTRL, $\mathrm{p}<0.05)$. After the transplant, we observed a trend to hypercalcemia in the HPTx group $(9.9 \pm 1.1$ vs. $9.5 \pm 0.6 \mathrm{mg} / \mathrm{dL}, p=0.06)$, which was marked after six $(10.2 \pm 0.7 \mathrm{mg} / \mathrm{dL}, \mathrm{p}<0.05)$ and 12 post transplant months $(10.5 \pm 0.8$ vs. $10 \pm 0.7 \mathrm{mg} / \mathrm{dL}, \mathrm{p}<0.05)$. Low phosphate levels were observed at 6 moths $(2.6 \pm$ 0.5 vs. $2.9 \pm 0.7 \mathrm{mg} / \mathrm{dL}, \mathrm{p}<0.05)$ and persisted over 1 year in the HPTX group. (Table 1)

Table 1 - Mineral metabolism markers during the first year post transplant, comparing patients with or without persistent hyperparathyroidism.

\begin{tabular}{|c|c|c|c|c|c|c|c|c|}
\hline & \multicolumn{2}{|c|}{ Calcium } & \multicolumn{2}{|c|}{ Phosphate } & \multicolumn{2}{|c|}{ Alkaline Phosphatase } & \multicolumn{2}{|c|}{ PTH } \\
\hline & CTRL & HPTx & CTRL & HPTx & CTRL & HPTx & CTRL & HPTx \\
\hline Transplant & $8.5 \pm 0.6$ & $8.9 \pm 0.9^{*}$ & $5.3 \pm 1.8$ & $6.0 \pm 1.8$ & n.a & n.a & $929 \pm 644$ & $\pm 1136.7 \pm 578.3$ \\
\hline M3 & $9.9 \pm 0.6$ & $9.9 \pm 1,5$ & $2.8 \pm 1.2$ & $2.5 \pm 1.5^{\star}$ & $109.0 \pm 52.0$ & $175.0 \pm 145.0^{*}$ & $166.9 \pm 92.2$ & $365.4 \pm 176.2^{*}$ \\
\hline M6 & $9.9 \pm 0.5$ & $10.2 \pm 0.7^{\star}$ & $2.9 \pm 0.7$ & $2.6 \pm 0.5^{*}$ & $100.5 \pm 46.0$ & $138.0 \pm 81.0^{*}$ & $118.8 \pm 62.6$ & $317.0 \pm 356.0^{*}$ \\
\hline M12 & $10.0 \pm 0.7$ & $10.5 \pm 0.8^{*}$ & $3.0 \pm 0.5$ & $2.9 \pm 0.6^{*}$ & $100.0 \pm 43.0$ & $135.0 \pm 88.0^{*}$ & $96.5 \pm 36.6$ & $317.6 \pm 225.9^{*}$ \\
\hline
\end{tabular}

${ }^{*} p<0.05$ versus control. N.A. not available 
Serum PTH and alkaline phosphatase differences between groups were observed in the first post transplant month, which persisted over time. While AP levels became normal at 3rd month, high PTH levels persisted in the 1st post TX year, despite of a comparable renal graft function.

\section{DISCUSSION}

Persistent post transplant hyperparathyroidism can be multifactorial. When there is recovery of the graft function, the severity of pre transplant bone mineral metabolism disturbance can alter the effects of the active vitamin $D$ synthetized by the graft on bone and intestinal calcium transport, maintaining the hypercalcemia. Furthermore, the lower vitamin $D$ levels observed during the first post transplant year can act as a persistent stimulus for the PTH synthesis. Isolated levels of PTH at the transplant, however, could not predict the incidence of HPTx. ${ }^{1,2,4}$

Despite the guidelines for bone mineral metabolism control in dialysis patients, higher PTH levels at transplant are often found. In the present series, $30 \%$ of patients had $\geq 500 \mathrm{pg} / \mathrm{ml}$ PTH levels at transplant, and they should be considered at high risk for HPTx.

In order to investigate the risks for HPTx, we excluded renal transplant recipients with graft dysfunction (serum creatinine $>2 \mathrm{mg} / \mathrm{dL}$ ) and we analyzed changes in the bone mineral metabolism markers in the first post transplant year. The earlier evidence for HPTx was hypercalcemia, which was observed in the first 2 weeks after transplant, and progressed during the 1-year follow up. Hypercalcemia could be a consequence of the increased intestinal calcium absorption or bone calcium reabsorption mediated by high PTH levels, as well as by the calcitriol synthetized by the functioning allograft. Higher levels of serum calcium at transplant can also be considered a marker or a risk factor for HPTx, since hypercalcemia in dialysis patients are usually associated with marked histological abnormalities in the parathyroid gland. Nodular parathyroid hyperplasia is associated with reduced expression of the calcium and vitamin $D$ receptors, leading to levels the autonomous production of PTH independent of the serum calcium levels. ${ }^{7}$ The early maintenance of hypercalcemia after transplant was considered a risk factor for persistent hyperparathyroidism in previous reports..$^{8-10}$
Another early finding in the HPTx group was hypophosphatemia observed in the 1stmonth and persisted over time. At transplant, severe hyperparathyroidism is associated with higher FGF-23 (fibroblast growth factor receptor 23) levels, a bone tissue derived fosfatonin that induces phosphate secretion by renal tubular cells, as well as inhibits vitamin $D$ hydroxylation by blocking its active form in the kidney. Higher FGF-23 levels early after transplant are associated with an increased renal phosphate excretion and hypophosphatemia. In transplanted patients, the use of calcineurin inhibitors can aggravate proximal tubular dysfunction, which can aggravate the hypophosphatemia by a direct effect on tubular cells. ${ }^{11-13}$

Persistent hyperparathyroidism is associated with high bone remodeling rate, which can be aggravated by immunosuppressive drugs such as steroids and calcineurin inhibitors. Serum alkaline phosphatase and PTH can be used as markers for bone remodeling rate. In this series, increased alkaline phosphatase levels persisted in HPTx group during the first year, suggesting that bone mineral disorder was not controlled, despite of normal renal graft function.

This study has some limitations: it is a single center retrospective analysis and we do not have a clear protocol to treat post transplant hyperparathyroidism. Furthermore, cinacalcet was not available for this population. The retrospective design of this study could not address the role of the vitamin $D$ deficiency as a trigger for persistent hyperparathyroidism.

\section{CONCLUSION}

In this series, incidence of persistent hyperparathyroidism after 1 post transplant year in patients with normal graft function was $13 \%$. From the baseline point (transplant), we noticed that $50 \%$ of patients with severe hyperparathyroidism achieved normal parathyroid function associated with recovery of the renal function. Risk factors for persistent hyperparathyroidism were longer pre transplant dialysis treatment; higher calcium levels at transplant and persistent post transplant hypophosphatemia.

Funding: no funding

Authors have no conflict of interest to declare. 


\section{RESUMO}

Hiperparatireoidismo persistente (HPTx) aumenta o risco de complicações após transplante renal. Objetivo: Identificar fatores de risco para HPTx no primeiro ano pós-transplante. Métodos: Análise retrospectiva de prontuários médicos de transplantados renais entre julho/2008 e dezembro/2010. Critérios de Inclusão: PTH sérico $\geq 500 \mathrm{pg} / \mathrm{ml}$ no transplante; função renal normal ao final de um ano (creatinina $\leq 2 \mathrm{mg} / \mathrm{dL}$ ). Dados analisados: cálcio sérico $(\mathrm{Ca})$, fosfatemia $(\mathrm{Pi})$, fosfatase alcalina sérica (AP), PTH e taxa de filtração glomerular (GFR) no transplante e nos meses 3, 6 e 12 póstransplante. Resultados: De 224 transplantes renais realizados no período, 69 (30\%) preencheram os critérios de inclusão e foram divididos em dois grupos, de acordo com os níveis de PTH após um ano de transplante: controle, PTH $<150 \mathrm{pg} / \mathrm{ml}(\mathrm{n}=32)$ e Hiperparatireoidismo persistente HPTx, PTH $\geq 150 \mathrm{pg} / \mathrm{ml}(\mathrm{n}=37)$. No transplante, os grupos eram comparáveis em relação à idade, fosfatemia e níveis de PTH. Entretanto, a duração de diálise pré-transplante ( $78 \pm 40$ vs. $50 \pm 34$ meses, $p<0,05)$ e calcemia $(8,9 \pm 0,9$ vs. $8,5 \pm 0,6 \mathrm{mg} / \mathrm{dL}, p<0,05)$ foram maiores no grupo HPTx. Após três meses, os níveis de PTH, $(365.4 \pm 176.2$ vs. $166.9 \pm 92.2 \mathrm{pg} / \mathrm{mL}, p<0.05)$ e de AP $(175 \pm 145$ vs. $109 \pm 52 U \mathrm{Ul}, p<0.05)$ foram significativamente maiores no grupo HPTx, apesar de filtração glomerular, calcemia e fosfatemia semelhantes aos controles. A partir do sexto mês pós-transplante, o grupo HPTx manteve hipercalcemia $(10,2 \pm 0,7 \mathrm{vs} .9,9 \pm 0,5 \mathrm{mg} /$ $\mathrm{dL}, p<0.05)$, hipofosfatemia $(p<0.05)$, e níveis mais elevados de PTH e fosfatase alcalina $(p<0.05)$. Ao final de um ano, apesar da recuperação da função renal, o grupo HPTx manteve hipercalcemia, enquanto no grupo controle, a normalização da função renal foi associada à normalização dos parâmetros do metabolismo mineral e ósseo. Conclusão: HPTx foi associado ao maior tempo de tratamento dialítico pré-transplante e maiores níveis de calcemia no transplante. Após o transplante, níveis mais elevados de PTH e fosfatase alcalina no terceiro mês também foram associados à maior incidência de HPTx, com persistência de hipercalcemia e hipofosfatemia, apesar da recuperação da função renal do enxerto.f the disease remains an obstacle to be overcome with new therapeutic strategies.

Keywords: Transplante; Hiperparatireoidismo; Hipercalcemia.

\section{REFERENCES}

1. Bacchetta J, Lafage-Proust $\mathrm{MH}$, Chapurlat R. Mineral and bone disorders in renal transplantation. Nephrol Ter. 2013;13:500.

2. Zhang R, Chouhan KK. Metabolic bone disease in kidney transplant recipients. World J Nephrol. 2012;5:127

3. Zhang R, Alper B, Simon E et al. Management of metabolic bone disease in kidney transplant recipients. Am J Med Sci. 2008;2:120

4. Kodras K, Haas M. Effect of kidney transplantation on bone. Eur J Clin Invest. 2006;S 2:63.

5. Jeon HJ, Han M, Jeong JC et al. Impact of vitamin D, bisphosphonate, combination therapy on bone mineral density in kidney transplant patients. Transplant Proc. 2013;8:2963

6. Saxena S, Sadideen H, Goldsmisth D. Treating stone in transplant kidneys. Minerva Med. 2013;1:31.

7. Nakamura M, Tanaka K, Marui Y et al. Clinicopathological analysis of persistent hypercalcemia and hyperparathyroidism after kidney transplantation in longterm dialysis patients. Ther Apher Dial. 2013;5:551.
8. Muirhead N, Zaltman JS, Gill JS et al. Hypercalcemia in renal transplant patients: prevalence and management in Canadian transplant practice. Clin Transplant 2014;28(2):161-5.

9. Torregrosa JV, Barros X. Management of hypercalcemia after renal transplantation. Nefrologia. 2013;33(6):751-7.

10. Isaksson E, Sterner G. Early development of secondary hyperparathyroidism following renal transplantation. Nephrol Clin Practice. 2012;121(1-2):c68-72.

11. Sirilak S, Chatsrisak K, Ingsathit A et al. Renal Phosphate loss in long -term kidney transplantation. Clin J Am Soc Nephrol. 2012;2:323.

12. Sánchez Fructuoso AI, Maestro ML, Pérez-Flores I et al. Serum level of fibroblast growth factor 23 in maintenance renal transplant patients. Nephrol Dial Transplant. 2012;11:4227.

13. Wesswling-Perry K, Pereira RC, Tsai E et al. FGF 23 and mineral metabolism in the early post-renal transplantation period. Pediatr Nephrol. 2013;11:2207. 